\title{
İLAÇ TAŞIYICI SİSTEMLER OLARAK POLİMERİK MİSELLERİN HAZIRLANMASI VE KARAKTERIZZASYONU
}

\section{PREPARATION AND CHARACTERIZATION OF POLYMERIC MİCELLES AS DRUG CARRIER SYSTEM}

\section{Zerrin SEZGIN, Nilüfer YÜKSEL*, Tamer BAYKARA}

Ankara University, Faculty of Pharmacy, Department of Pharmaceutical Technology, 06100, Tandoğan-Ankara, TURKEY

\section{ÖZET}

Bu derlemede, polimerik misellerin ilaç taşıyıcı sistemler olarak son yıllardaki kullanımları üzerinde yoğunlaşılmıştır. Sulu çözeltilerinde, çözünürlüğ̈̈ zayıfmaddelere karşı yüksek çözündürme kapasitesi olan dayanıkl yapıdaki polimerik miselleri meydana getiren amfifil kopolimerlerin yapısı ve özellikleri tanımlanmıştır. Misellerin oluşum mekanizmaları ve etkin madde yüklenmesi hakkında genel bilgiler verilmiştir. Polimerik misellerin karakterizasyonuna ve avantajlarına değinilmiştir. Derlemenin son bölümünde ise polimerik misellerin medikal tanı amaçl görüntüleme, ilaç hedefleme, immünoloji, gen terapisi ve oral ilaç taşınması gibi değiş̧ik farmasötik alanlarda kullanımlarıyla ilgili örnekler verilmiştir.

Anahtar Kelimeler: Polimerik miseller, Amfifilik ko-polimerler, Kritik misel konsantrasyonu, İlaç Taşıyıcı Sistemler, İlaç hedefleme, Kontrast ajan

\begin{abstract}
This review concentrates on the use of polymeric micelles as pharmaceutical carriers in recent years. The structure and properties of the amphiphilic block co-polymers that form stable polymeric micelles having high loading capasity towards poorly soluble pharmaceuticals are described. General Information on the mechanisms of micelle formation and drug loading process is given. Characterization and advantages of micelles are considered. The last section of the review focuses on the potential medical applications of polymeric micelles in medical diagnostic imaging, drug targeting, immunology, gene therapy and oral drug delivery.
\end{abstract}

Key Words: Poymeric micelles, Amphiphilic co-polymers, Critical micelle concentration, Drug carrier system, Drug targeting, Contrast agent 


\section{I-GİRISŞ:}

Etkin madde parçalanmasını ve kaybını en aza indirmek, zararlı yan etkilerini önlemek, biyoyararlanım ve etki yerlerinde bulunan oranlarını artırmak için, çeşitli etken madde salım sistemleri ve hedefleme sistemleri geliştirilmiştir. Bu sistemlerden bazıları lipozomlar, nano-birleşimler (associates), nanopartiküller, etkin madde-polimer konjugatlan ve polimerik misellerdir. Son yıllarda özellikle polimerik miseller üzerinde artan bir ilgi söz konusudur [1].

\section{İlaç taşıyıcı sistemler olarak miseller şu avantajları sağlamaktadırlar [2]:}

* Çözünürlüğü düşük etkin maddeleri çözünür hale getirmekte ve böylece biyoyararlanımlarını artırmaktadırlar.

* Gerekli bölgede etkin maddenin toplanabilmesini sağlamak için vücutta yeterli derecede uzun bir süre kalabilmektedirler.

* Nanometre boyutlarında büyüklüğe sahip olmaları, onların zayıf damarlanmanın olduğu bölgelerde birikmelerine olanak sağlamaktadır.

* Spesifik ligandlar bağlanarak hedeflendirilebilmektedirler.

* Büyük miktarlarda, kolaylıkla ve tekrarlanabilir bir şekilde üretilebilmektedirler.

* İçlerindeki etkin maddeyi biyolojik ortamda inaktivasyondan koruyabilmektedirler ve istenmeyen yan etkiler gözlenmemektedir.

\section{II- Polimerik Miseller:}

Misel oluşturan düşük molekül ağırlıklı farmasötik surfaktanların toksisiteleri azdır ve çözünürlüğü az olan maddelere karşı çözünürleştirici etkileri vardır. Ancak kritik misel konsantrasyonları (c.m.c) yüksek olduğundan, seyrelmeyle (örn: IV veriliş sonucu kanla seyrelme sonucu) dayanıklı halleri bozulur. Bu nedenle daha düşük c.m.c'na sahip dayanıklı misel oluşturabilecek surfaktan molekülleri araştırılmış, bunun sonucu olarak sulu ortamda polimerik miseller oluşturan amfifil blok kopolimerler (rasgele, di-blok, tri-blok ve graft kopolimerler gibi) üzerinde ilaç taşıyıcılar olarak çalışılmaktadır [3-5]. Amfifilik blok kopolimerler, hidrofilik ve hidrofobik monomer ünitelerinden oluşmuşlardır ve sulu çözeltilerde yüksek çözündürme kapasiteli ve dayanıklı yapıda küresel miseller oluştururlar.

Misellerin morfolojik olarak hidrofobik bloklardan meydana gelen çekirdek ve hidrofilik polimer zincirleriyle dayanıklı hale getirilmiş koronadan (bir misel yapısındaki amfifilik 
kopolimerlerin hidrofob uçlarını tanımlayan terim) oluşan, küresel partiküller olduğu kabul edilmektedir. Bununla birlikte araştırmalar, blok kopolimerlerden oluşan agregatların küreler, çubuklar, veziküller, lamel yapılar, hekzagonal olarak yerleşim gösteren içi boş halkalar gibi çok sayıda farklı misel benzeri şekiller halinde bulunabileceğini göstermektedir [6-8]. Kopolimerler sulu ortamda blok kopolimerin bileşimine, kopolimer konsantrasyonuna, koronayı oluşturan hidrofilik zincirler arasındaki etkileşimlere, ortama asit, baz veya tuz katılmasına, kullanılan organik çözücülere, çözücünün polaritesine ve blokların çözücüdeki bağıl çözünürlüklerine bağlı olarak farklı morfolojiler meydana getirebilmektedir. Farklı morfolojiler kontrollü koşullar altında tekrarlanabilir bir şekilde oluşturulabilmektedir, ancak etkin madde şahmında yararlılıkları belirlenememiştir.

\section{II-I- Polimerlerden Misel Oluşumu:}

Amfifilik polimerlerden misel oluşumunun altında yatan termodinamik düzenlemeler, düşük molekül ağırlıklı amfifıl maddelerin miselizasyonundakilerle aynıdır.

Misel oluşumu başlıca iki kuvvetin sonucu olarak meydana gelmektedir; moleküllerin bileşimine neden olan çekim kuvveti ve misellerin ayrı bir makroskobik faz halinde sınırsız büyümelerini önleyen itici kuvvet. Amfifilik kopolimerler, hidrofilik veya hidrofobik bloktan ikisinden birisi için seçici olan bir çözücü içine konulduklarında kendiliklerinden birleşmektedir. Miseller oluşurken c.m.e altında amfifil konsantrasyonu arttıkça su-hava arayüzeyinde adsorblanan amfifilin konsantrasyonu da artar. Daha fazla amfifil eklenmesiyle miselleri oluşturmak üzere amfifil maddeler birleşirler [9]. c.m.c ve biraz yukarısında miseller gevşektirler ve çekirdeklerinde az da olsa su içerirler. Ortamdaki amfifil konsantrasyonu biraz artırılınca misel dengesi misel oluşumu tarafına kayar. Miseller daha sıkışık ve dayanıklı olur. Çekirdeklerindeki artık çözeltiyi kaybederler ve boyutlarını küçültürler.

Kopolimerlerin tiplerine bağlı olarak farklı tipte miseller oluşabilmektedir [2] 


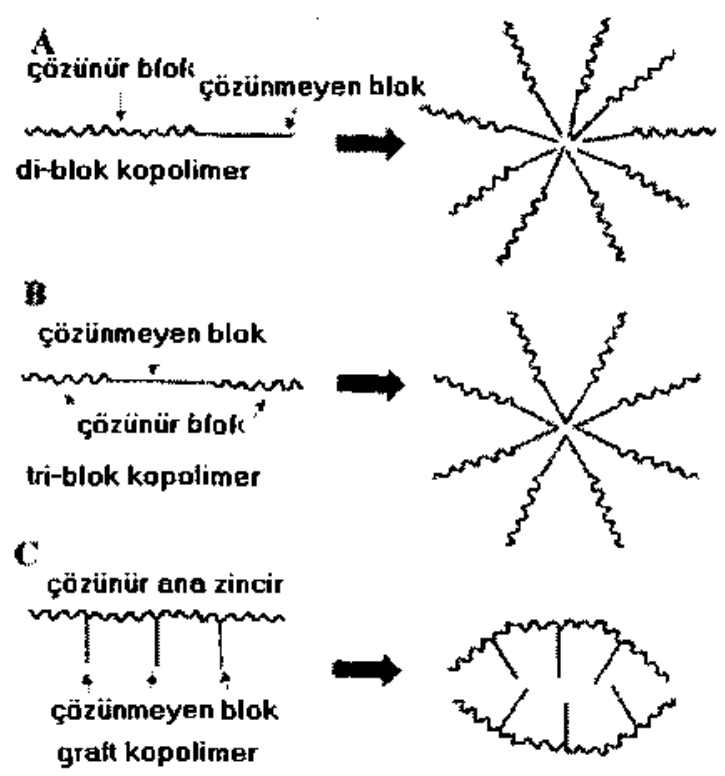

Şekil 1: Farklı tipte amfifilik kopolimerlerden misel oluşumunun mekanizması [2]

\section{1-2- Misel Oluşturucu Kopolimerlerin Yapısı ve Özellikleri:}

Polimerik miseller üzerindeki farmasötik araştırmalar başlıca di-blok kopolimer yapısı üzerinde yoğunlaşmıştır [1]. Genel olarak yapılan çalışmalarda araştırmacılar amaçlarına uygun hidrofilik-hidrofobik blok kombinasyonunda miselleri oluşturduğundan bu alanda çeşitlilik söz konusudur. Pekçok çalışmada polietilenoksit (PEO yani PEG) hidrofilik bloğu oluştururken hidrofobik blok olarak çok sayıda farklı materyal kullanılmaktadır. Aşağıda çekirdek oluşturucu blok olarak kullanılan biyolojik olarak geçimli hidrofobik polimerlerden bazıları verilmiştir [6]:

* Poli(aspartik asit) [10]

* Poli(beta-benzil-L-aspartat) $[11,12]$

* Polikaprolakton [13]

* Poli(gama-benzil-L-glutamat) [14]

* Poli(D,L-laktid) [15]

* Poliakrilik asit [7]

* Poli(oksi propilen) [16]

* Oligo(metil metakrilat) [17]

* Polistiren [18] 
Amfifilik kopolimerlerde PEO'in yaygın olarak kullanılma nedeni, suda çözünürlüğünün yüksek olması, çeşitli mikropartiküller için ve nanopartiküller için sterik bir koruyucu olması ve çeşitli hidrofobik bloklarla kolayca konjuge edilebilmesidir [6, 19]. Diğer bir hidrofilik materyal ise poli(akrilik asit) olmuştur, misel yüzeyinde negatif yük sağlayan biyoadhezif bir polielektrolittir. Bu durumun uzun süreli mukozal etkin madde salımı için yararlı olabileceği belirtilmektedir [17].

Misel oluşturan blok kopolimerler, hidrofilik-hidrofobik bloklarının uzunlukları kontrol edilerek farklı HLB ve molekül ağırlıklarında (MA 1000-10000 Da) sentezlenmektedirler. Kopolimerlerin fizikokimyasal ve biyolojik özellikleri, farklı blokların kopolimer içindeki molar oranları ile kontrol edilebilmektedir. Kopolimerlerin oluşturulmasında kullanılan blokların çeşitliliğine bağlı olarak misellerin fizikokimyasal özellikleri ve etkin madde taşıyıcısı olarak uygunlukları farklı olmaktadır. Belirli bir etkin madde için uygun olan bir misel çekirdeği diğeri için uygun olmayabilir ayrıca blok kopolimerlerin sentezi de oldukça güçtür. Bu nedenle ancak bir parametre yani çekirdek bloğu uzunluğu değiştirilebilmekte ve bu değişkenliğin miselin çap, dayanıklılık, etkin madde yükleme kapasitesi ve salımı üzerine etkileri beklenmektedir. Zaten misel özelliklerini etkileyen tüm parametrelerin etkin madde salımı alanında sistematik olarak incelenmesinin gerçekçi olmayabileceği belirtilmektedir. $\mathrm{Bu}$ kısıtlamalar gözönüne alındığında ticari olarak bulunan bir blok kopolimer olan polipropilenoksit-polietilenoksit (Pluronics ${ }^{\circledR}$ ), misellerin çalışılmasında uygun bir materyal olmuş ve pek çok çalışmada kullanılmıştır $[16,20]$.

\section{1-3- Polimerik Misellerin Hazırlanması:}

Başlıca iki temel hazırlama yöntemi vardır (Şekil 2):

- Doğrudan çözme yöntemi

- Diyaliz yöntemi. 


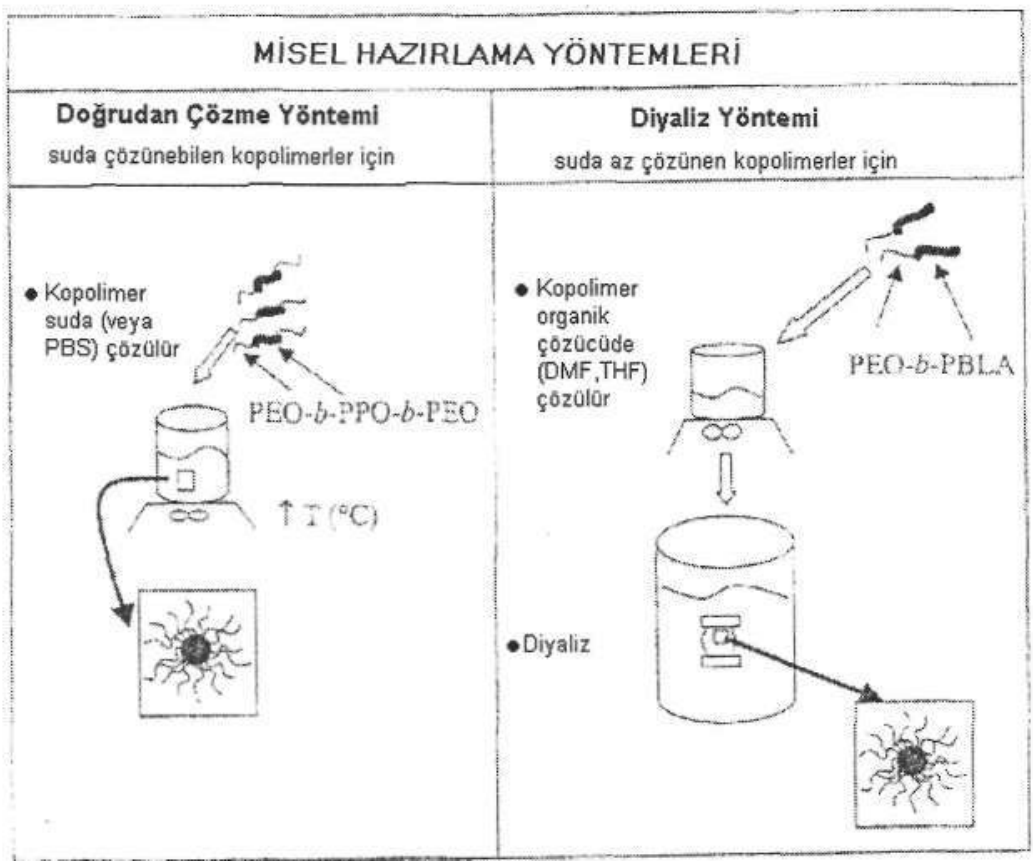

Şekil 2: Blok kopolimer misellerin hazırlanmasında uygulanan iki temel yöntemin şematik gösterimi. [6]

Yöntemin seçimi, büyük ölçüde blok kopolimerlerin su içindeki çözünürlüğüne bağlıdır. Eğer kopolimer suda çözünebiliyorsa doğrudan çözme yöntemi; kopolimer suda çok az miktarda çözünüyorsa diyaliz yöntemi uygulanmaktadır.

Doğrudan çözme yönteminde, kopolimer (örn: Pluronicler [16]) su veya diğer sulu ortamlara ilave edilmektedir; bazı durumlarda kopolimer ve suyun misel oluşumunu sağlamak için yüksek sıcaklıklarda karıştırılması gerekebilmektedir.

Diyaliz yöntemi ise suda çözünmeyen kopolimerlerin öncelikle su ile karışabilir bir organik çözücüde (tetrahidro furan, dimetilasetamid, dimetilformamid) çözülmesini ve daha sonra bidistile suya karşı diyaliz edilmesini içermektedir [6]. Genellikle misellerin hazırlanması için bu yöntem kullanılmaktadır. Kullanılan kopolimerlere polietilenoksit-b-poli-(3-benzil-Laspartat [6] örnek olarak verilebilir. Çekirdeği koronasından daha büyük olan miselleri (crewcut miseller) oluşturan kopolimerler de suda çözünmez. (Örn: polistiren-b-poliakrilikasit [7], poli-e-kaprolakton-b-polietilenoksit [6], polistiren-etilenoksit [18]). Bu nedenle kopolimer bir organik çözücüde çözüldükten sonra üzerine yavaşça su eklenir. Kritik su içeriğine ulaş1lınca miseller oluşur. Karışımdaki organik solvan bidistile suya karşı diyaliz edilir veya organik çözücü rotavapor ile uçurulur. 


\section{1-4- Misellere Etkin Madde Yüklenmesi:}

Çözünmeyen etkin maddeler, miseller içine kimyasal konjugasyon veya fiziksel olarak diyaliz ya da emülsifikasyon teknikleri ile yüklenebilmektedir. (Şekil 3) [1]. Proteinler gibi hidrofilik bileşiklerin miseller içine yüklenmesi, molekülün kimyasal olarak hidrofob hale getirilmesini gerektirmektedir $[10,21]$. İyonik etkin maddelerin miseller içine yüklenmesi, kopolimerin hidrofobik bloğu üzerinde karşıt yük bulunmasını gerektirmektedir. Bir etkin madde hidrofobik bloğa kimyasal veya elektrostatik olarak bağlanacak ise bu etkin maddenin misel içine birleştirilmesi, misel oluşumu ile aynı anda yürütülmektedir. Güçlü polimer-ilaç etkileşimi misel içine yüklemeyi artırır ancak misellerden ilaç şahmını azaltır. $\mathrm{Bu}$ nedenle yükleme seviyesinin ve ilaç salım kinetiklerinin optimize edilmesi gerekir.

Yükleme kapasitesi ve etkinliğinin etkin maddenin yapısı, çekirdeği oluşturan bloğun yapısı, çekirdeği oluşturan bloğun total uzunluğu, total kopolimer MA'1, etkin madde konsantrasyonu, çekirdek oluşturucu blok ile etkin madde arasındaki geçimlilik ve daha az derecede ise hidrofil bloğun uzunluğu ve yapısı ile değiştiği belirtilmektedir.

a
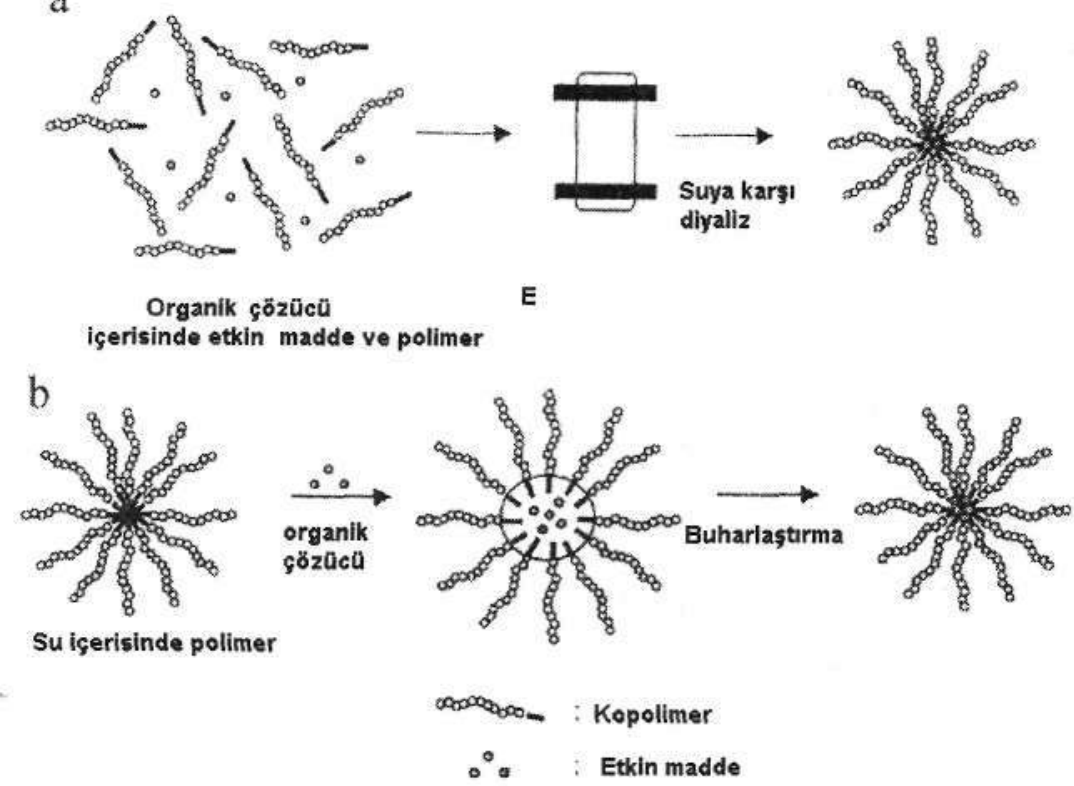

Şekil 3: Polimerik misellere etkin madde yüklenmesi (a)diyaliz yöntemi, (b)y/s emülsiyon yöntemi [1]

\section{II-5- Polimerik Misellerin Karakterizasyonu:}

Kritik misel konsantrasyonun (c.m.c), dayanıklılığın, misellerin çap ve çap dağılımlarının tayin edilmesi gereklidir. Teorik olarak c.m.c'da veya yakınında aniden değişiklik gösteren herhangi bir fiziksel özellik, örneğin arayüzey gerilimi [22], iletkenlik, ozmotik basınç gibi, c.m.c tayini için kullanılabilmektedir. Kritik misel konsantrasyonu, 1şık saçılımı, gaz 
permeasyon kromatografisi (GPC) yöntemleri [1], piren gibi floresan maddelerle yapılan spektroflorometrik ölçüm [17, 23], sudan boyası kullanılarak yapılan spektrofotometrik ölçümlerle tayin edilebilir [16].

Misellerin çapları ve polidispersitesi ise su veya izotonik tampon içersinde dinamik ışık saçılımı ile belirlenebilmektedir [13, 14, 23]. Bunların yanında morfolojilerinin de incelenebilmesini sağlayan iki yöntem transmisyon (TEM) ve tarayıcı (SEM) elektron mikroskobileri ile AFM (atomic force microscopy)dir [7, 13, 14].

Polimerik misellerin stabilitelerinin tayini de karakterizasyonları için önemlidir. Hedef bölgede misellerin birikmesi, etkin madde salımı için yeterli zamanın sağlanması ve aynı zamanda vücuttan kolayca elimine edilebilmeleri için yavaş bir şekilde birimlerine ayrışmaları gerekir. Misellerin in vitro ve in vivo stabiliteleri ve vücuttan atılımları c.m.c değerlerine dayanmaktadır. Bir miselin c.m.c'u pekçok faktörden etkilenmektedir. Bunlar çekirdeği oluşturan bloğun yapısı ve uzunluğu, hidrofilik bloğun uzunluğu ve çözünmüş hidrofobik maddelerin bulunmasıdır. Misellerin in vivo stabilitesi açısından düşük bir c.m.c tercih edilmektedir.

Misellerin termodinamik stabiliteleri unimenmisel dengesinin unimer yönüne kaydığ konsantrasyon alt değerini, kinetik stabiliteleri ise c.m.c altında ayrışma hızlarını ifade etmektedir. Misellerin kinetik stabiliteleri misel çekirdeğinin fiziksel durumuna, çekirdek içindeki çözücü içeriğine, hidrofobik blok uzunluğuna ve hidrofilik/hidrofobik oranı kapsayan pekçok faktöre bağlıdır [1,2].

Misel çekirdeğinin intrinsik viskozluğu misellerin fiziksel stabilitelerini ve ilaç salımını etkiler. Hidrofob çekirdeğin intrinsik viskozitesi (veya mikroviskozitesi) bis(l-pirenil-metil)eter (dipyme) veya 1,6-difenil-1,3,5-hekzatrien (DPH) gibi floresan maddeler kullanılarak tayin edilebilir. H-nukleer magnetik rezonans (NMR) da misel çekirdeğinin intrinsik viskozluğu hakkında bilgi verir.

\section{İdeal bir misel sisteminin taşıması gerekli özellikler şunlardır [6]:}

*Bir bütün olarak miselin boyutu $100 \mathrm{~nm}$ 'den küçük olmalıdır ki retiküloendotelyal sistem tarafindan tutulmasın ve böylece hücre ve dokulara girişi mümkün olsun.

*Etkin maddenin farmakokinetik parametreleri ve organ biyodağılımında tahmin edilemeyen değişiklikleri önlemek için dar bir çap dağılımına sahip olmalıdır.

*İn vivo verilişte dayanıklı olmalıdır, c.m.c'u düşük olmalıdır ve misel yapısı yavaşça bozulmalidir. 
*MiseIin koronası çekirdeği yeterli derecede örterken etkin bir sterik engel olarak da rol oynamalıdır.

*Miselin çekirdeği yüksek bir yükleme kapasitesine sahip olmalı ve kontrollü bir etkin madde salımı sağlamalıdır.

\section{III- Polimerik Misellerin Farmasötik Alanda Kullanımları:}

Küçük çap, yüksek çözünürlük, basit sterilizasyon, kontrollü etkin madde salımı gibi özellikleri nedeniyle polimerik misellerin ideal ilaç taşıyıı sistemler olduğu düşünülmektedir. Polimerik misellerin teorik olarak uygulama bulabileceği farmasötik alanlar medikal tanı amaçlı görüntüleme, bölgesel ilaç hedeflendirmesi, immünoloji, gen terapisi ve oral ilaç taşınmasıdır.

\section{1-1- Polimerik Misellerin Medikal Tanı Amaçlı Görüntülemede Kullanımları:}

Günümüzde tıbbi görüntüleme yapmak amacıyla gama sintigrafı, magnetik rezonans (MR), bilgisayarlı tomografi (CT) ve ultrasonografiden yararlanılmaktadır [24]. Hangi görüntüleme tekniği kullanılırsa kullanılsın, ilgilenilen dokuyu diğerlerinden ayırabilmek için o dokudan gerekli sinyalin alınabilmesi gerekmektedir. Bu amaçla kullanılan kontrast ajanlar herbir yönteme özgüdür ve ilgilenilen dokuda yeterli miktarda birikerek uygun yöntemle görüntüleme olanağı sağlarlar.

Gama sintigrafi ve magnetik rezonansla görüntüleme yapmak amacıyla kullanılan teşhis ajanları misellere yüklenmiştir (Şekil 4). MR pozitif (Ti) kontrast ajanı tasarımı için şelatlanmış paramagnetik metal birimleri ( $\mathrm{Gd}, \mathrm{Mn}$ gibi) ilgi çekmişlerdir. Genelde şelatlanmış metal iyonları hidrofilik karakter gösterirler ancak, misellere yüklenebilmeleri için amfifil yapıda olmaları gerekmektedir. (DTPA-PE (dietilentriaminopentaasetik asid fosfatidiletanolamin), DTPA-SA (dietilentriaminopentaasetik asid stearilamin) ile $\mathrm{Mn}$ ve Gd'un açillenmiş paramagnetik amfifil kompleksleri gibi.) Bu ajanlarda hidrofilik şelatlayıcı kısım hidrofobik zincire kovalan bağlıdır. Molekülün lipid bölümü miselin hidrofobik çekirdeğine bağlanır. Daha hidrofilik şelat ise miselin hidrofilik kabuğunda lokalize olur. $\mathrm{Bu}$ ve benzeri şelatlar gama görüntüleme için misellerin ağır radyometallerle $\left({ }^{\mathrm{H} 1} \mathrm{In}\right.$ gibi) yüklenmesinde de kullanılabilirler. Misellerin kontrast ortam olarak etkinliklerini artırmak için taşıyıcıya bağlı raportör metallerin (Gd veya ${ }^{1 \mathrm{n}}$ In gibi) miktarı artırılabilir böylece sinyal şiddeti artmaktadır.

Torchilin ve arkadaşları [24] bu amaçla amfifil polişelatlayıcı N,a- (DTPA-polylisil glutaril fosfatidil etanolamin sentezlemişlerdir. Bu şelatlayıcı kolayca misel çekirdeğine yüklenebilmektedir ve birtek lipid anchora bağlanan şelatlanmış Gd atom sayısını artırmaktadır (Şekil 4). Artan Gd içeriği ise alınan MR sinyal şiddetinin artmasını sağlamaktadır. 
Lenfatik görüntüleme amacıyla amfifilik şelatlaycı problar (Gd $\left({ }^{\mathrm{n} 1} \mathrm{In}\right)-\mathrm{DTPA}-\mathrm{PE} \mathrm{ve}{ }^{\mathrm{H1}} \mathrm{In}$ DTPA-SA) $20 \mathrm{~nm}$ çapındaki PEG(5kDa)-PE misellerine yüklenmiştir. Bu partiküler ajanlar tavşanlarda $y$-sintigrafı ve MR görüntüleme teknikleri kullanılarak perkütan lenfografıde kullanılmıştır [25].

111-Ifi işaretli DTPA-SA/PE misellerinin subkutan olarak uygulama sonucu lokal lenfatiklerde lokalizasyonu gözlenmiştir. Miseller lenf akışının izlenmesini sağlarken diğer lenfotropik kontrast ortamlarda ise olay onların nodal makrofajlarca aktif alımları olmaktadır.

Çekirdeğine amfifil İllin veya Gd içeren Polişelatlayıcı Amfifilik Polimerler (PAP) yüklenmiş PEG-PE karışık misellerinde yapılan benzer deneyler sonucunda da değişik lenf sistemi bölmelerinde hızlı ve etkin gama ve MR görüntülemesi yapılmıştır. Miseller yüzeylerindeki PEG'in koruyucu etkisinden dolayı nodal makrofajlara birikmeden lenf sıvısında kalmış ve lenfatik yolla hızla uzaklaştırılırmıştır.

Kontrast yüklü misellerin tamamen dayanıklı olduğu ve gama sintigrafı veya $\mathrm{MR}$ izlemede etkin ve hızlı olarak kullanılabilecekleri belirtilmektedir.
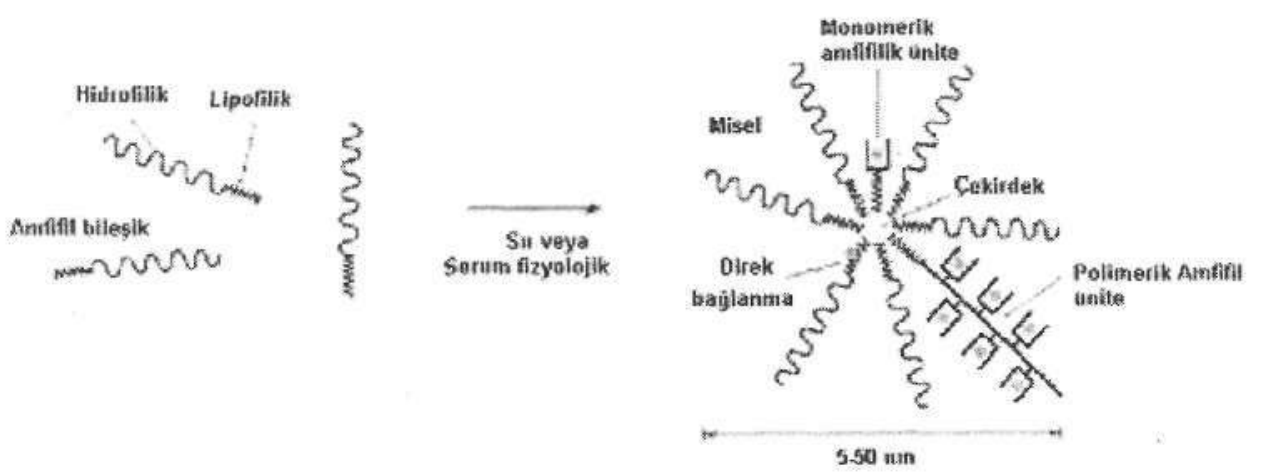

Şekil 4: Misel oluşumu ve bu partiküler sistemin farklı bölümleriyle birleşebilecek değişik tanı ajanlarının yüklenmesi [24].

III-2- Kan Havuzunun Bilgisayarlı Tomografiyle(CT) görüntülenmesi amacıyla polimerik misellerin kullanımı:

Kan havuzunun incelenmesi mevcut kan akış durumunun değerlendirilmesi ve arteriosklerotik lezyonlar, trombus veya tümörden kaynaklanan düzensizliklerin saptanabilmesi için önemlidir. 
$\mathrm{Bu}$ incelemelerde uzun süre sirküle edebilen, genelde kontrast özellikli, sterik olarak korunmuş, polimerlerce modifiye edilmiş mikropartiküller kullanılmaktadır.

. Günümüzde kullanılan partiküler kontrast ajanlar büyük boyuttadırlar $(0.25-3.5 \mid 0 . \mathrm{m})$ ve aktif bir şekilde fagositozla atılmaktadır. Bu nedenle dağılımı kan havuzuyla sınırlı olan materyal hazırlamak için partikül büyüklüğü kapiller açıklıktan $(>10 \mathrm{~nm})$ daha büyük, fagositoza dirençli ve yapısal olarak partikül içine yüklenmiş radyopak birimi olan ajanlar hazırlanması gerekmektedir. Sulu ortamda 10-80 nm'lik dayanıklı ve uzun sirkülasyona sahip miseller oluşturan amfifil polimerler bu gereksinimleri karşılayacaktır.

Kan havuzunun CT görüntülenmesi için çekirdeğinde iyot içeren Metil-polietilenglikolpropiyonik asit ve poli(karbobenzoksi)-L-lizin'den sentezlenmiş, 50-70 nm boyutunda ve toplam ağırlı̆̆ının \%30-35'i iyot olan polimerik miseller hazırlanmıştır, in vivo çalışmalarda bu polimerik misellerin uzun süre sirküle ettiği gözlenmiştir. Polimerik misellerin teşhis amaçlı kullanılabilirliğinin kanıtlanması için miseller CT kontrast ajanı IV olarak sıçanlara ve tavşanlara enjekte edilmiş ve değişik organlardan CT tarayıcı kullanarak X 1şını sinyali görüntülenmiştir. Enjeksiyondan 2 saat kadar sonra kan havuzunda (aort ve kalpte) 3-4 katlık belirgin bir artış gözlenmiştir [25].

\section{III-3- Misellerin hedeflemede kullanımları:}

Miseller hedeflendirilmiş ilaç taşıyıcıları olarak kullanılabilirler. Misellerle 3 temel hedeflendirme mekanizması gözlenir:

1) Bunlardan birincisi gevşek damarlanma boyunca miselin interstisiyuma kendiliğinden penetrasyonu ile olur (EPR etkisi) ve pasif hedefleme olarak adlandırılır [26]. Difüzyon ve birikme parametreleri, tümör damar çeperinin por büyüklüğüne bağlıdır ve tümörün tipine göre değişir. (Şekil 5)

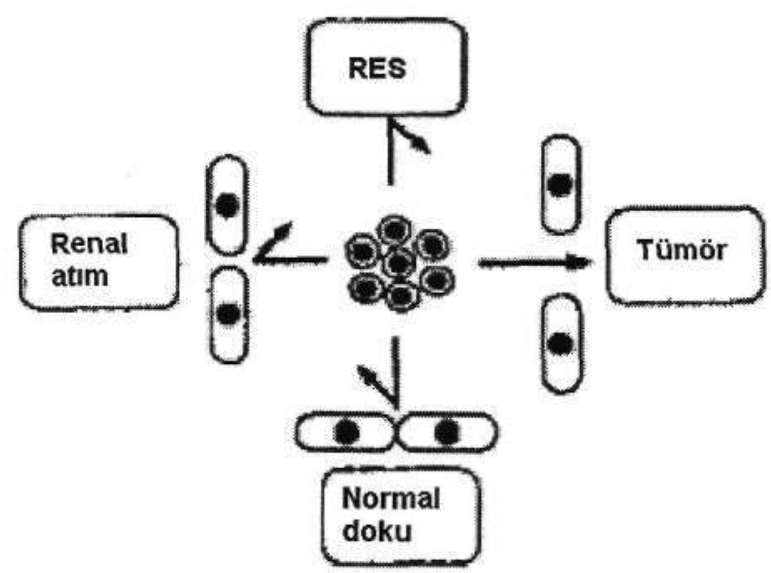

ipekli 5: Polimerik misellerin tümörlerde birikmesi [1]. 
2) $\mathrm{Bu}$ hedefleme mekanizması ise farklı doku ve organlarda lokal sıcaklık artması ve/veya asidozla patolojik olayların oluşmasına dayalı fiziksel hedeflemedir. Sıcaklık ve pH'ya duyarlı maddelerden hazırlanmış miseller, (örn: poli(N-izopropilakrilikamid) ve onun poli(D,Llactid)le ve diğer bloklarla oluşturulan kopolimerleri gibi) bu bölgelerde parçalanarak içeriğindeki ilacı salarlar [27]. (Şekil 6)

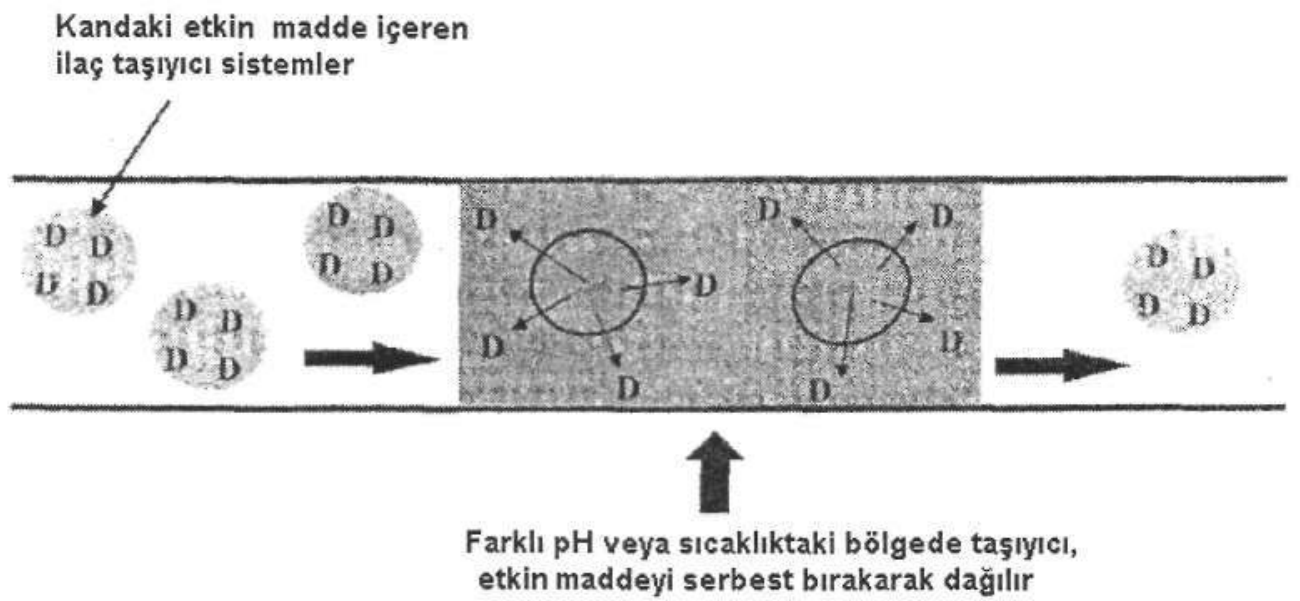

Şekil 6: İlaç/ilaç taşııııı sistemlerin fiziksel hedeflendirilmesi [19].

3) Bir diğer hedefleme ise özgül vektör molekülleriyle yapılır. Antikorlar gibi özgül ligantlar hidrofilik blokların suya maruz kalan uçlarına bağlanabilir. Bu durumda antikor için herhangi bir sterik engel olmadan miselleri hedeflendirmek için seçilen antikor veya onun bir bölümü aktive edilmiş hidrofilik blokların suya maruz kalan uçlarına bağlanabilir ve hedefleme yapılır [28].

Kataoka ve arkadaşları [29] yaptıkları bir çalışmada hidrofobik bir antikanser ilaç olan Adriamisini poli (etilen oksit)-poli (aspartik asit) blok kopolimerine konjüge ederek polimerik miseller (PEO/PASP(ADR) hazırlamışlardır.) $\mathrm{Bu}$ polimerik misellerin in vivo olarak fare adenokarsinomasına (colon26) karşı antikanser aktivitesi araştırılmıştır. Sc olarak transplante edilen ve büyüyen katı tümörlerin tedavisinde PEO/PASP(ADR) misellerin etkinliğinin parenteral ADR'den daha fazla olduğu görülmüştür. (Şekil 7)

PEO/PASP(ADR) misellerinin ekstravasküler tümörlerdeki bu mükemmel etkinliği polimerik misellerin damar dışı dokulara ve özellikle de katı tümörlere spesifik olarak ilaç taşımada kullanılabileceğini göstermiştir. 


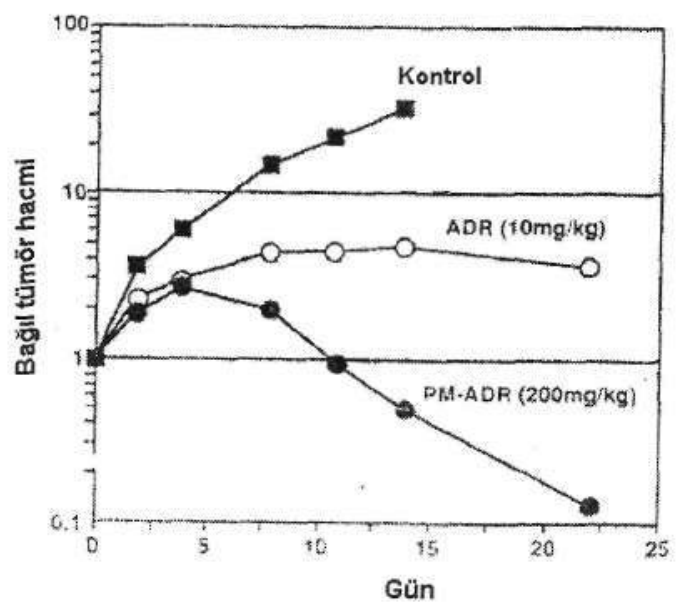

Şekil 7: Fare adenokarsinomasına (Colon26) karşı in vivo antikanser aktivitesi. Tümörlü sıçanlara IV enjeksiyonla (4 gün arayla $3 \mathrm{doz}$ ) serbest ADR veya ADR içeren polimerik miseller optimum dozajda verilmiştir [29].

Kabanov ve arkadaşları poli(oksietilen)-poli(oksipropilen) blok kopolimeriyle (Pluronic) hazırladıkları 12-36nm boyutlarındaki miselleri kullanarak beyne ilaç hedeflendirilmesi üzerinde çalışmışlardır $[16,30,31]$, Etkin madde yüklü misellerin invivo olarak sıçanlara uygulandıktan sonraki dağılımlarını görmek amacıyla FITC (Florosein izotiyosiyanat) ilaç modeli olarak kullanılmıştır. Serbest FITC ve miseller çözeltisi IV veya intraperitonal olarak uygulanmıştır. Serbest ve Pluronic P85 misellerinde çözündürülmüş FITC'dan elde edilen sonuçlardan IV ve intraperitonal verilişin benzer olduğu görülmüştür. FITC'ın dağılımında en önemli fark akciğerler, karaciğer ve beyinde görüldüğü için bu organlar incelenmiştir. Fare dokularındaki maksimum floresans uygulamadan 1 gün sonra ortaya çıkmıştır. FITC'ın pluronic misellerde çözündürülmüş halinde floresansın beyin, kalp, böbrek, karaciğer ve akciğerlerde giderek arttığ 1 görülmüştür. Pluronic P68, P85, L64 serilerinde penetrasyon etkinliğinin artan Pluronic hidrofobluğuyla yükseldiği görülmüştür.Misel büyüklüğünün de dağılımı etkilediği belirlenmiştir. Büyüklüğü mikrometre aralığında olan P85+L101 misellerinin daha küçük boyuttaki P85 misellerinden daha çok karaciğerde tutulduğu gözlenmiştir.

Etkin madde içeren Pluronic misellerini beyne hedeflendirmek amaciyla beyin glial hücreleri antijenine (a-glikoprotein ,GP) karşı olan anti-a $a_{2}-G P$ antikoru ve insülin (Ins) vektör molekülleri kullanılmıştır. Elde edilen akciğer ve beyin floresan mikrofotolarında Ins konjuge 
edilmiş misellerin vektörsüz olana göre beyin dahil tüm dokulardaki floresansı artırdığı görülmüştür. Anti-a - -GP antikorunun vektör olarak kullanılması halinde ise akciğerlerde tutulan FITC miktarı azalırken beyindeki floresans miktarı artmıştır. $\mathrm{Bu}$ da misellere yüklenen antikorun beyindeki glia hücrelerindeki antijenlerle etkileştiğini göstermektedir.

Aynı grup çalışmacı Anti-a - GP antikorlarını ve insülini vektör olarak içeren Pluronic misellere Haloperidol yüklemiş ve sonuçta vektör içeren Pluronic misellerin çözündürülmüş nöroleptiklerin kan-beyin engelinden geçişinde ve beyindeki dopamin reseptörlerindeki etkisinin artmasında etkin olduğu gözlenmiştir.

\section{HI-4- İmmünolojide misellerin kullanımı:}

Polimerik misellerin bir diğer ilginç kullanım alanı ise immünolojidir. Non iyonik blok kopolimerler (özellikle Pluronik) immün cevabın modülasyonu ve yeni/etkin aşıların hazırlanması için immünolojik adjuvanlar olarak kullanılmışlardır. Pluroniklerin makrofaj aktivasyonunu artırdıkları ve adjuvan özelliklerini miseller veya emülsiyon formda gösterdikleri belirtilmektedir. Yüksek molekül ağırlıklı Pluronikler çeşitli antijenlerle yüklenebilecek miseller oluşturmaktadırlar. Bu misellerin yüksek adjuvan etkisi influenza virüs aşısıyla gösterilmiştir [32].

\section{1-5- Gen Terapisinde Polimerik misellerin kullanımı:}

Polimerik misellerin ilaç taşınmasında kullanıldığı bir diğer alan da gen terapisidir. Gen terapisinde hedeflemede kullanılan viral vektörlere göre sentetik vektörler emniyet, immunojenesite ve üretim kolaylığı açısından daha üstündürler. IV injeksiyon bölgesinin uzağındaki hedef hücrelere etkin gen taşıma sistemleri geliştirmek için polikatyon ve PEG'in blok kopolimerleri kullanılarak poliyon kompleks miselleri hazırlanmış. Bu miseller gen taşıma vektörlerinde aranan suda çözünebilme, nukleaza rezistant olma ve kanda dayanıklı olma özelliklerini karşılarlar. Bu misellerle karaciğer, arter duvarı ve akciğere gen taşıma çalışmaları vardir.

\section{III-6- Polimerik Misellerin Oral İlaç Taşınmasında Kullanımları:}

Polimerik misellerin oral yolla veriliş için de potansiyele sahip olduğu belirtilmektedir. Lipofilik bir ilacın oral verilişinden sonra biyoyararlanımının artması, barsaklarda doğal olarak diyet yağının sindirilmesiyle oluşan safra lipidlerini içeren karışık misellerin oluşması sonucu ilacın çözünürleştirilmesiyle olur. Etkin maddenin miseller formu, intestinal mukozal 
membrandan enterositler içine transfer edilmektedir ki burada lipoprotein biyosentetik yolağına girmekte ve sonuçta şilomikron partiküUeri içine birleşmiş olarak intestinal lenfatikler içersine salınmaktadır. Bu şekilde misellerin sadece Iipofilik etkin maddelerin değil polar ve hatta peptid ve proteinleri içeren makromoleküllerin de biyoyararlanımını artırdığı belirtilmektedir [2]. Bu şekilde polimerik misellerin oral yolla veriliş için potansiyele sahip olduğu kaydedilmektedir.

Hoffman ve arkadaşları AB tipi blok kopolimer olan oligo(metil metakrilat) ve poli(akrilik asit) ile hidrofobik ilaçların miseller taşınması üzerinde çalışmışlardır. Miselin koronasını oluşturan poli(akrilik asit)' in biyoadhezif yapıda olması nedeniyle oral ilaç taşıması için uygun oldukları belirtilmiştir [17].

Peptit ve protein etkin maddelerin oral şahmında da partikül absorpsiyonu fenomeninin kritik rolüne bağlı olarak polimerik miseller intestinal mukozadan absorpsiyon için potansiyel peptit-protein taşıyıcı sistemler olarak görülmektedir.

\section{IV-SONUÇ}

Küçük çap, yüksek çözünürlük, basit sterilizasyon, kontrollü etken madde salımı gibi belirgin avantajları nedeniyle polimerik misellerin ideal ilaç taşıyıcı sistemleri olduğu görülmektedir. Bugüne kadar özellikle misellerle antikanser etkin maddelerin parenteral verilişi üzerinde yoğunlaşılmıştır. Bununla birlikte polimerik miseller teorik olarak, sürekli etki, oral salınım, immünoloji, medikal tanı amaçlı görüntüleme ve bölgeye özgü etken madde hedeflemesi gibi çeşitli farmasötik alanlarda uygulama bulabilecek sistemlerdir.

\section{LITERATÜRLER:}

1. M.-CJones, J.-C.Leroux, "Polymeric micelles-a new generation of colloidal drug carriers" Eur. J. Pharm. Biopharm. 48, 101-111 (1999).

2. V.P.Torchilin, "Structure and design of polymeric surfactant-based drug delivery systems" J. Contr. Rel. 73, 137-172 (2001).

3. M.Yokoyama, "Block copolymers as drug carrier" Crî̂. Rew. Ther. Drug Car. Syst. 9, 213248 (1992).

4. A. Gennaro, Remington The Science and Practice of Pharmacy, 20th ed ed. 2000, Philadelphia: Lippincott Williams\&Wilkins. 926. 
5. V.P.Torchilin, "PEG-based micelles as carriers of contrast agents for different imaging modalities" Adv. Drug. Deliv. Rev. 54, 235-257 (2002).

6. C.Allen, D.Maysinger, A. Eisenberg, "Nano-engineering block copolymer aggregates for drug delivery" Coll. Surf. B. Biointerf. 16, 1-35 (1999).

7. L.Zhang, A.Eisenberg, "Multiple morphologies and characteristics of "crew- cut" micellelike Aggregates of Polystyrene-b-poly(acrylic acid) Diblock Copolymers in Aqueous Solutions" J. Am. Chem. Soc.118, 3168-3181 (1996).

8. N.S.Cameron, M.K.C., A. Eisenberg, "1998 E.W.R. Steacie Award Lecture Asymetric amphiphilic block copolymers in solutions: a morphological wonderland" Can. J. Chem. 77, 1311-1326(1999).

9. A.Martin, J., Swarbrick, A,Cammarata, Physical Pharmacy 2nd ed. 1970, Philadelphia: Lea\&Febiger. 447.

10. T.Aoyagi, K.S., Y.Sakurai, T.Okano, K.Kataoka, "Peptide drug carrier: studies on incorporation of vasopressin into nano-associates comprising poly(ethylene glycol)-poly(Laspartic acid) block copolymer" Coll. Surf. B. Biointerf, 16, 237-242 (1999).

11. G.Kwon, M.N., M.Yokoyama, T.Okano, Y.Sakurai, K.Kataoka, "Block copolymer micelles for drug delivery: loading and release of doxorubicin" J. Contr. Rel. 48, 195-201 (1997).

12. J.Liaw, T.A., K.Kataoka, Y.Sakurai, T.Okano, "Permeation of PEO-PBLA-FITC Polymeric Micelles in Aortic Endothelial Cell" Pharm. Res. 16(2) (1999).

13. S.Y.Kim, I.G.S., Y.M.Lee, Y.K.Sung, T.Akaike, C.S.Cho, "Methoxy polyethylene glycol) and e-caprolactone amphiphilic block copolymeric micelle containing indomethacin. II. Micelle formation and drug release behaviors" J. Contr. Rel. 51, 13-22 (1998).

14. Y.I. Jeong, J.B.C., S.H. Kim, J.W. Nah, Y.M. Lee, Y.K. Sung, T. Akaike, C.S.Cho, "Clonazepam release from core shell type nanoparticles in vitro" J. Contr. Rel. 51 169-178 (1998).

15. X.Zhang, J.K.J., H.M. Burt, "Development of amphiphilic diblock copolymers as micellar carriers of taxol" Int. J. Pharm. 132, 195-206 (1996).

16. A.V.Kabanov, E.V.B., N.S.Melik-Nubarov, N.A.Fedoseev, T.Yu.Dorodnich, V.Yu.Alakhov, V.P.Chekhonin, I.R.Nazarova, V.A.Kabanov, "A new class of drug 
carriers: micelles of poly (oxyethylene)-poly(oxypropylene) block copolymers as microcontainers for drug targeting from blood in brain" J. Contr. Rel. 22, 141-158 (1992).

17. T.Inoue, G.C., K.Nakamae, A.S.Hoffman, "An AB block copolymers of oligo(methyl methacrylate) and poly(acrylic acid) for micellar delivey of hydrophobic drugs" J. Contr. Rel. 51,. 221-229(1998).

18. M.Wilhelm, C.L.Z., Y.Wang, R.Xu, M.A.Winnik, J.L.Mura, G.Riess, M.D.Croucher., "Poly(styrene-ethylene oxide) block copolymer micelle formation in water: a fluorescene probe study" Macromolecules, 24, 1033-1040 (1991).

19. V.P.Torchilin, "Drug Targeting" Pharm.Sci. 11(2), S81-S91 (2000).

20. G.S.Kwon and T. Okano, "Soluble self-assembled block copolymers for drug delivery" Pharm. Res 16(5), 597-600 (1999).

21. V.S.Trubetskoy, V.P.T., "Polyethyleneglycol based micelles as carriers of therapeutic and diagnostic agents" S.T.P. Pharma Sciences, 6, 79-86 (1996).

22. A.V.Kabanov, I.R.N., I.V.Astafieva, E.V.Batrakova, V.Y.Alakov, A.A.Yaraslovov, V.A.Kabanov, "Micelle formation and solubilization of fluorescent probes in poly(oxyethylene-b-oxypropylene-oxyethylene) solutions" Macromolecules, 28, 2303-2314 (1995).

23. I.G.Shin, S.Y.K., Y.M.Lee, Y.K.Sung, TAkaike, CS.Cho, "Methoxy polyethylene glycol) /e-caprolactone amphiphilic block copolymeric micelle containing indomethacin. I. Preparation and characterization" J. Contr. Rel. 51, 1-11 (1998).

24. V.P.Torchilin, "Polychelating amphiphilic polymers to optimize the concentrations of contrast agents used in medical diagnostic imaging" Chemtech, 29(11) 27-34 (1999).

25. V.S.Trubetskoy, M.D.F.-K., K.R. Whiteman, G.L. Wolf, V.P.Torchilin, "Stable polymeric micelles: lymphangiographic contrast media for gamma scintigraphy and magnetic resonance imaging" Acad. Radiol, 3, 232-238 (1996).

26. A.N. Lukyanov, Z.G., L. Mazzola, V.P.Torchilin, "Polyethylene Glycol-Diacyllipid micelles demonstrate increased acculumation in subcutaneous tumors in mice" Pharm. Res., 19(10), 1424-1429 (2002). 
27. -F.Kohori, K.S., T.Aoyagi, M.Yokoyama, Y.Sakurai, T.Okano, "Preparation and characterization of thermally responsive block copolymer micelles comprising poly $(\mathrm{N}-$ isopropylacrrylamide-b-DL-lactide)" J. Contr. Rel, 55, 87-98 (1998).

28. V.P.Torchilin, A.N.L., Z. Gao, L. Mazzola, "Polymer-lipid micelles as non-targeted and targeted pharmaceutical carriers" Polymer Preprints, 43(2) 677-678 (2002).

29. K.Kataoka, G.S.K., M.Yokoyama, T.Okano, Y.Sakurai, "Block copolymer micelles as vehicles for drug delivery" J. Contr. Rel, 24 119-132 (1993).

30. E.V.Batrakova, H.H., D.W.Miller, A.V.Kabanov, "Effects of Pluronic P85 unimers and micelles on drug permeability in polarized BBMEC and Caco-2 cells" Pharm. Res., 15(10), 1525 (1998).

31. A.V.Kabanov, E.V.B., V.Yu.Alakhov, "Pluronic block copolymers as novel therapeutics for drug and gene delivery" J. Contr. Rel, 82, 189-212 (2002).

32. M.J.Newman, M.B., C.W.Todd, "Development of adjuvant-active nonionic block copolymers" Adv. Drug. Deliv. Rev., 32, 199-223 (1998).

Received: 04.03.2003

Accepted: 02.06.2003 